\title{
Hospital management of severe bronchopulmonary dysplasia
}

\author{
Corrado Moretti, Caterina S Barbàra, Rosanna Grossi, Stefano Luciani, Paola Papoff \\ From XXI Congress of the Italian Society of Neonatology \\ Palermo, Italy. 24-26 September 2015
}

Despite early surfactant therapy, betterventilator strategies and greater use of noninvasive positive pressure ventilation, bronchopulmonary dysplasia (BPD)continues to be a complication of premature births.

The mainstay of supportive care for infants with severe BPD is mechanical ventilation with an endotracheal tube, however treatmentcan last for a long time and have many complications. When safe extubation is not possible because of multiple failed attempts, tracheostomy is sometimes recommended [1-5]. In all age groups outside the neonatal period, placement of a tracheostomy is considered after a few weeks of mechanicalventilation [6,7]. By contrast, the optimum time and safety procedures have not yet been determined for the placement of a tracheostomy in infants with BPD who need protracted ventilation. Reasons for not performing a tracheostomy in these patientsinclude technical concerns associatedwith small patient size or the need for high ventilator settings. On the other hand the placement of a tracheostomy early in the course of severe BPD could have positive effects such as improved comfort, decreased need for sedation, lower systemic corticosteroid exposure, and enhanced nutrition and growth.

Recent data [8] suggest that a reasonable approach is that chronically ventilated infants should be assessed at 3 months of age, that is around or shortly after 40 weeks corrected gestational age. If the respiratory support remains high and has been so for 2 months with no evidence of improvement and after multiple attempts to wean the baby off positive pressure ventilation, then infants should be considered for a tracheostomy placement. Another important point highlighted by this report is that tracheostomies should be considered a safe

\footnotetext{
* Correspondence: corrado.moretti@uniroma1.it
Pediatric Emergency and Intensive Care, Department of Pediatrics, Policlinico

* Correspondence: corrado.moretti@uniroma1.it "Umberto I", Sapienza University of Rome, Rome, Italy
}

procedure even in infants on high pressures and high concentrations of supplemental oxygen.

Other results [9] suggest a potential association between earlier ( $<120$ days) tracheostomy and better neurodevelopmental outcomes. Actually, while an infant awaits a tracheostomy, the medical focus is often on strategies to allow weaning and limit ventilator-associated lung injury. Following a tracheostomy, the focus may shift to maximizing parent-child interaction and developmental improvement. Furthermore, after tracheostomy, there is often an opportunity to wean the baby off sedating medications, which are frequently associated with increased risk of neurodevelopmental impairment.

In conclusion tracheostomy does not mitigate the significant risk for adverse neurodevelopment that is associated with the many complications of prematurity; however, if tracheostomy is to be performed, earlier surgery may allow opportunities for enhanced neurodevelopmental outcomes.

\section{Published: 24 September 2015}

\section{References}

1. Papoff P, Cerasaro C, Caresta E, Barbàra CS, Midulla F, Moretti C: Current strategies for treating infants with severe bronchopulmonary dysplasia. JMaternFetal Neonatal Med 2012, 25(Suppl 3):15-20.

2. Overman AE, Liu M, Kurachek SC, Shreve MR, Maynard RC, Mammel MC Moore BM: Tracheostomy for infants requiring prolonged mechanical ventilation: 10 years' experience. Pediatrics 2013, 131(5):e1491-e1496.

3. Viswanathan S, Mathew A, Worth A, Mhanna MJ: Risk factors associated with the need for a tracheostomy in extremely low birth weight infants. PediatrPulmonol 2013, 48(2):146-150.

4. Grover TR, Brozanski BS, Barry J, Zaniletti I, Asselin JM, Durand DJ, Short BL, Pallotto EK, Dykes F, Reber KM, Padula MA, Evans JR, Murthy K: High surgical burden for infants with severe chronic lung disease (sCLD). J Pediatr Surg 2014, 49(8):1202-1205.

5. Murthy K, Savani RC, Lagatta JM, Zaniletti I, Wadhawan R, Truog W, Grover TR, Zhang H, Asselin JM, Durand DJ, Short BL, Pallotto EK, Padula MA, Dykes FD, Reber KM, Evans JR: Predicting death or tracheostomy placement in infants with severe bronchopulmonary dysplasia. J Perinatol 2014, 34(7):543-548. 
6. Brook AD, Sherman G, Malen J, Kollef MH: Early versus latetracheostomy in patients who require prolonged mechanicalventilation. Am J Crit Care 2000, 9(5):352-359.

7. Carron JD, Derkay CS, Strope GL, Nosonchuk JE, Darrow DH: Pediatric tracheotomies: changing indications and outcomes. Laryngoscope 2000, 110(7):1099-1104.

8. Mandy G, Malkar M, Welty SE, Brown R, Shepherd E, Gardner W, Moise A, Gest A: Tracheostomy placement in infants with bronchopulmonary dysplasia: safety and outcomes. Pediatr Pulmonol 2013, 48(3):245-249.

9. DeMauro SB, D'Agostino JA, Bann C, Bernbaum J, Gerdes M, Bell EF, Carlo WA, D'Angio CT, Das A, Higgins R, Hintz SR, Laptook AR, Natarajan G, Nelin L, Poindexter BB, Sanchez PJ, Shankaran S, Stoll BJ, Truog W, Van Meurs KP, Vohr B, Walsh MC, Kirpalani H, Eunice Kennedy Shriver National Institute of Child Health and Human Development Neonatal Research Network: Developmental outcomes of very preterm infants with tracheostomies. J Pediatr 2014, 164(6):1303-1310.

doi:10.1186/1824-7288-41-S1-A23

Cite this article as: Moretti et al:: Hospital management of severe bronchopulmonary dysplasia. Italian Journal of Pediatrics 2015 41(Suppl 1): A23.

\section{Submit your next manuscript to BioMed Central} and take full advantage of:

- Convenient online submission

- Thorough peer review

- No space constraints or color figure charges

- Immediate publication on acceptance

- Inclusion in PubMed, CAS, Scopus and Google Scholar

- Research which is freely available for redistribution

Submit your manuscript at www.biomedcentral.com/submit 